\title{
HISTORY OF CONFESSIONAL POETRY IN INDIAN WOMEN WRITINGS A SHORT OVERVIEW
}

\author{
Dr Richa Mishra \\ Dr. Hitesh D. Raviya
}

\begin{abstract}
'Confessional' is an adjective first applied to the poems of the American poets Robert Lowell, Anne Sexton, Sylvia Plath, W.D. Snodgrass, John Berryman and Theodore Roethke to refer to the autobiographical nature of their work. The confessional poet considers the world, an extension of herself. All confessional poetry springs from the need to confess; confessional poets bare their soul and body and hide nothing between their self and their direct expression of that self. They put no restrictions on subject matter, no matter how personal. Usually anti-elegant and anti- establishment, confessional poems are almost like war-cries triumphing over pain and defeat. The best confessional poems are more than confessions: they are revelations, about their creator's personal vexations, dilemmas and predicaments, and above all about the human condition. This review work tries to prove that confessional poetry was always present in Writings by women in India. This work is a literature review of known writings by women in India.
\end{abstract}

KEY WORDS: Women writings, History, India, Oppression, Confessionalism.

We are all alike,

We women,

In our wrappings of hairless skin.

Kamala Das

The literary landscape of India is one of the most exciting, yet daunting and compulsive in the whole world, eighteen officially recognized languages, over 400 dialects and a 5000 year old civilization (according to UNESCO world language Atalas) have made the different region of this country differently. Yet throughout the country History from the pre-Aryan time to the present, writing has traditionally been 
the domain of the men, and according to Adrienne (2017) women's writing has been ignored. The spot light was mostly on the other side of gender.

India with a history of ancient civilization such as the Harappa and Mohanjodaro and scriptures like Vedas, Upanishads and Puranas finds few and far mention of women writers and scholars. In Vrahadaranyak Upanishads mention of "Gargi Vachaman is present who discourses with Yagya Valakya.

The emergence of the first body of poetry by women exists predating the $6^{\text {th }}$ century B.C. It could be attributed to the advent of Budhism. The period between the writing of $\underline{V e d a s}$ and $6^{\text {th }} \mathrm{BC}$ does not have prominent mention of any women scholars.

During the Aryan times the few mentions of poetical work done by women which find mention in the book "Wonder That Was India" by, A.L. Bhasam are done mainly by courtesans and the prostitutes. Courtesans were patrons of art and culture. The mention of low society women who can also practice writing was also present but "Sabhrant" or respectable women were expected to be a good wife, nurturing mother and home maker.

The freedom and enlightenment provided by the Budhhism poured a new energy into the writing of women and her stature. This religion offered freedom and the principle of equality. The free mind and soul broke the shackles of home life. The rapture of joy felt by the women is manifested in the earliest known anthology of women's literature in India as those belonging to the Therigatha nuns. These poets were contemporaries to the Budha. One of these, Mutta, writes joyously :

So free am I, so gloriously free from three

things mortar from pestle

and from twisted lord.

( "Mutta"1'-2)

The work has been translated from the Pali. It offers the insight of women's like and their frustration with the life inside the home. The choice to join Buddhist Sangtha 
(religious communities) was their attempt to break away from the social realm of tradition role restrictions and bondage of marriage.

The emerged poems were the testimony of freedom from house hold chores and sexual slavery.

The celebration of personal freedom was followed by the poetry bursting with the joy of women hood and sexuality. The paradigm shift from sexual slavery to enjoyment of sensuality throws the light on changed mentality of women.

The sangam poets that dominated the era between ca. 100 BC-AD 250 were the precursor of confessional poetry in India. These poems were laced with new found sexuality with explicit details. The translations of Venmanippati Kuruntokai's "What She Said to Her Girl Friend":

On the banks shaded by a punnai clustered with flowers when we made love my eyes saw him and my ears heard him.

My arms grow beautiful in the coupling and grow lean as they came away.

(Tharu and Lalitha 68)

The content of the poem was bold and echo of sexual liberation was present in this and many other poems.

As Tharu and Lalitha pointed out these were the folk songs women used to sing while transplanting seedings, drawing water and husking paddy. The folk song almost like ballads took the form of poetry.

The poems of the Sangam age, which was translated by A.K. Ramanujam pointed out the disparities in gender. The poems almost confessionalism in nature, were extensively of women experiences. The poems were haunting echo of the need of bodily love and passion, the foolishness and worthlessness of war and the spears that men left with to wage wars. 
The ten anthologies and eight long poems of the Sangam were the prominent work of that period.

Among the poets who found mention in the $12^{\text {th }}$ century A.D. came the medieval Kannada poet, rebel and mystic A.K. Kamala Devi, who challenged the patriarchal dominance by her writings and her life.

The spread of Budduhism and advent of Islam forced culture change and change in position of women. The alien culture of Purdah and other customs forced Hinduism to reinvigorate itself, so as to survive. A revision of spirituality resulted in the new found outlook of the Bhakti movement. The followers of this movement showed hint of confessionalism in the sense of depicting themselves and their body image as a poetic subject. Akkamaha devi says.

Brother your come drawn

By the beauty of these billowing

Breasts, this brimming youth.

I am no women brother

No whore.

(Tharu and Lalitha 79)

As a radical mystic, she uses the symbol of her genitals to portray four hundred thousand gods and goddesses of Hinduism. She plays with the words and beautifully, coveys the idea of rebirth when she says

Not one not two, not three or four,

but through eight four hundreds thousand

vagina's have I come. I have come through

unlikely worlds guzzled on pleasure and pain

(Tharu and Lalitha 80)

Another poet writes in a revelation mode as

In my harlots trade having taken one man's money

I daren't accept a second man's sir

And If I do, they will stand me naked and kill me, sir,

( Tharu and Lalitha 81 ) 
The growth of poetry, especially women poetry in different dialects reflected economic hardships of most women. The tradition of earlier poets' who used to write about religion and God, now wrote about the discriminatory alignment of the oppressive caste system.

Janabal, the Varkari saint poet of the low caste Sudra community of Maharastra compares her compassionate follow sweeper who aids her when she tires, to God. There are other examples also of the lower caste women criticizing and mocking the Hindu caste system.

The rise of Islam brought a new set of experiences and influences to women literature. The first novel biography namely Humayun Nama was composed by Princess Gal Badan Begum. Muddupalini a courtesan wrote five hundred and eighty four poems about Krishna and Radha with third section consisting of Radha's sexual advances towards Kirshna. Her compositions of bold advances of Radha stunned most liberal of critics and readers. As Tharu and Lalita points out

The courts of Princes and kings were great patron of arts and literature. They granted extensive patronage to women educated in the art of dance and music. One Ramabhadramba of Tanjaour courts, Mahlaga Bai Chanda were some of the courtesans who wrote beautifully (120)

In $18^{\text {th }}$ century combination of factors led to the decline of women writing. Since the establishment of East India Company, princes and kings lost their kingdom and was restricted to the small Privy Purse, there was loss of patronage to women in courts. The association of courtesans with education took a negative meaning. Education was associated with 'bad women'. This led to the loss of education for women and production of women literature came to the stands still.

With the reformist movement in the late $19^{\text {th }}$ century India saw women's active participation in rebelling against British rule. This also spurred the development of women literature in India. Writers like Bhabhai and Jogeswari questioned the patriarchal dominance of their husbands. Bhabani defied Vedas and Puranas :

The Vedas cry aloud, the Puranas shout

No good may come to a commonly 
I was born with a woman's body

How am I to attain truth.

They are foolish seductive deceptive

Any connection with a woman is disastrous

Bahina says "If a woman's body is so harmful. How in the world will I reach truth? (qtd. in Koshy)

Due to British rule, education in English gained foot. There were woman poets who were educated in English as well, among them Ramabai Saraswati, Toru Dutt, Aru Dutt, and Sarojini Naidu were prominent.

Toru Dutt whose life was a mosaic of tragedy and fatality and beauty was the precursor of Indo-Anglican poetry. Enriched with a rich and respectable ancestry, she had perfect surroundings for the sensibilities of a poet. Her father Govin Chander Dutt, a good linguist and a cultured man with literary leanings attracted by the glamour of the west, embraced Chrishantity. The family with fine sensibility and poetical in temperament left for Europe in 1869. The girls Aru Dutt and Toru Dutt knew both French and English. But the years in Europe were harsh on Toru Dutt. The tragic death of her sister and brother did not deter her to translate and write French writings into English. Her work appeared in 1857 as A Sheaf Gleaned in French Fields. Toru Dutt was appreciated by none other than Edmund Gosse, who read the book with surprise and almost rapture. Toru Dutt's later poems also exhibits sprinkling of confessionalism. "In Our Casuarian Tree" she evoke tree. She try to recapture the past, and then immortalize the moments of time so recaptured. The third stanza of the five stanza long poems links the tree with memories of her lost brother and sisters

But not because of its magnificence

Dear is the casuarinas to my soul;

Beneath it we have played though year may roll

O Sweet companion loved with love intense,

For your stakes shall the tree be ever dear!

Blend with your images, It shall arise

In memory, till the hot tears blind mine eyes. 
What is that dirge-like murmur that I hear like the sea breaking an a shingle beach.

It is the Trees lament, eeric speech,

That happily to the unknown land may reach.(23-33)

Other poems also mention her mother, brother and sister.

Sarojini Naidu (1879-1947) was one of the most gifted poet who readily shared her burden of pain. She articulated agonies and hopes in her poems.

Her young life was a roller-coaster ride, of a girl student; cupid struck teenage, exiled student and later a wife. This was followed by motherhood's privileged pains and joys. She wrote in the spirit of confessionalism. The personal 'l' was almost visible in her poems. In the last volume, disillusioned and bitter sweet she wrote

And how you flung the throbbing heart that loved you

To serve wild dogs for meat?

They bring me saffron veils and silver sandals

Rich crowns of honour to adorn my head-

For none save you may know that the tragic secret,

O love, that I am dead! ("The Secret" 7-12)

Her brilliant poems dazzle the reader with powered words, emotions and sentiments endowed with the gift of oration. She entered into politics and there also with her astonishing word play she astonished the listeners.

Her first volume of poetry in 1905 The Golden Threshold silenced the critics who said that women cannot write poems. The second volume of poems The Bird of Time came out in 1912; the volume was spread with songs of life and death.

The change in note can be seen in Sarojini Naidu's third and final collection. The Broken Wing which was published in 1917. This volume consisted of poems addressed to her father, to Gokhale, MK Gandhi and other. These later poems of Naidu was more subjective in nature, the subject of the work was based on her own life's experience. The lines strewn with resentment, boldness, bite of anger and heat of passion burst in "The Path of Tears"

Why did you turn your, face away? 
Was it for love or hate?

Or the spell of that wild miraculous hour

That hurled our souls with relentless power

In the eddying fires of fate?

(Section I, "The Sorrow of Love "6-10)

She, for her writing these lines of sustained passion was compared with Mrs. Browning's sonnets "From the Portuguese". The third poem in the second section blazes with fury

The tumult of your own willed heart shall smiles

With strong and sleepless pinions of desire.

The subtle hunger in your veins shall bite your

With swift and unrelenting fanges of live

When youth and spring passion shall you

And mock your proud rebellion with defeat.

God knows, O love, if I shall save or slay you

As you lie spent and broken at my feet.

("The Menace of love")

Whereas in "The Sanctuary", The Eighth poem "Devotion" reverberates with despair:

Take my flesh to feed your dogs if you choose,

Water your garden - trees with my blood if you will,

Turn my heart into ashes, my dreams into dust-

Am I not yours, O Love, to cherish or kill?

Strangle my soul and fling it into the fire!

Why should my true love falter or fear or rebel?

Love, I am yours to lie in your breast like flower,

Or burn like a weed for your sake in the flame of hell?

The Broken Wing was almost a heart wrenching, agonized cry of personal experience. This was the last collection of Sarojini Naidu's although she lived for another 32 years. 
The last poem of Naidu palpitating with confessional mode found their true inheritor in the writings of New Poet of Kamala Das.

The end of World War II rustles up hope along with stirring of despair. It gave rise to a new generation, who at a cross road of old and new were striving to strike individuality of its own.

The tone, the content, the sharpness, and its feature all were new. The contemporary poetry in England, in France and in the States was the poetry of protest. This new Indo-Anglican poetry surges with a new urgency to break tradition. The poets, of modern poetry had their vision unfaltering and clear to a future.

Kamala Das with her scintillating writings and rendering founded the genre of confessionalism in Indo-Anglican poetry. In a true sense of Confessional poetry her poetry springs from the need to confess.

She wrote in the pattern and mode of several "moden' American poets. Always in the vortex of controversy, Kamala Das hails from the Southern Malabar in Kerala. The green sylvan surroundings nestled her grandmother's house. She lived with her Nayar father and Nalapat mother beside the roaring sea. She was born on March 23, 1934

As her autobiography tells us, her father belonged to a traditional family, having an aristocratic atmosphere surrounding it. Her father had been employed in an automobile company in Calcutta. Kamala Das Madavikutty first attended a European school in Calcutta then the elementary school at Panayur Kulam, (her birth place) and later a boarding school run by the Roman Catholic nuns where she got ill and was removed to Calcutta, where with the help of private tutors she learned her fine arts. Her grand uncle Nalapat Narayana Menon was a "Poet Philosopher" and her mother Balamany Amma, was a renowned poet in Malayalam.

Literary by attitude Das was equally impressed with the Malayalam literature which left a deep influence in molding her attitude to life. Speaking of her parents she wrote 
My mother did not fall in love with my father. They were dissimilar and horribly mismatched. But my mother's timidity helped to create an illusion of domestic harmony.... Out of such an arid union were born the first two children, my brother and I, bearing the burden of a swarthy skin and ordinary features( M S 5).

My Story details the description of her own marriage as unsatisfying and unfulfilling and her poems present the image of a marriage lifeless, empty, and dull. She wrote about her husband

He was obsessed with sex. If it was not sex, it was the co-operative movement in India and both these bored me. But I endured knowing that there was no escape from either, I even learnt to pretend an interest that I never once really felt (127). The monstrous ego of her husband stopped her from growth

As she later wrote in the poem "Old Playhouse"

Cowering

Beneath your monstrous ego I ate the magic loaf and

Became a dwarf. I lost my will and reason to all your Questions I mumbled in coherent replies. $(15-17)$

Art imitates life and vice versa. Art always decipher trends of the society. The dominance of men parallels both mythical literature and history. The literature written by women manifests this again and again. The women writings in all culture and all ages were almost the repressed creative selves, and confessions were always associated with a cathartic, healing power. As observed Judith Harris observes in the abstract of her book Signifying Pain Constructing and Healing the Self Through Writing Women and misfit men make sense through writing of their experience of mental illness and of their treatment. Harris stresses the importance of taking individual suffering into the public realm and comes to the conclusion that these themes all speak of the refusal of their role of victim.

The confessional poetry emerged as the "self-revelation of poets or writers of their dilemma, predicament and loss. This is one of the most prominent themes in women writings. 


\section{Works Cited}

Das, Kamala. My Story. Sterling Publishers Pvt. Ltd., 1976.

---. Summer in Calcutta. Everest Press, 1965.

---. The Descendants. Writers Workshop, 1967.

---. The Old Playhouse and Other Poems. Orient Longman Ltd., 1973.

---. My Story. Sterling Publishers Pvt. Ltd., 1976.

Das, Kamala. "When the Temptress Dons the Purdah." Interview by George lype. Rediff, 14 Dec. 1999, www.rediff.com/news/1999/dec/14kamala.htm.

"Dialogue between Gargi and Yajnavalkya." Upanishads, upanishads.org.in/stories/dialogue-between-gargi-and-yajnavalkya. Assessed 11 February 2020.

Dutt, Toru. Toru Dutt Poems. Poem Hunter, www.poemhunter.com/toru-dutt. Assessed 11 February 2020.

lyengar, KRS, Indian writing in English. Sterling Publishers Pvt. Ltd, 2003.

Koshy, Sherin. "A world of words, lost and found: a brief overview of women's literature in India from the 6th century BC onwards." Literature Study Online, www.literature-study-online.com/essays/indian-women-writers.html. Assessed 11 February 2020.

Rivera, Adrienne. "The History and Importance of Women's Literature." Books Tell You Why, 11 August 2017, blog.bookstellyouwhy.com/the-history-andimportance-of-womens-literature. Assessed 11 February 2020.

Tharu, Susie and Lalitha, K. Editors. Women Writing in India volume, I 600 BC to The Early Twentieth Century. Oxford University Press, 1991.

\section{Dr Richa Mishra \\ Professor of English \\ Department of Mathematics and Humanities, Institute of Technology, Nirma University, Ahmedabad, Gujarat E-mail: richa.mishra@nirmauni.ac.in \\ \& \\ Dr. Hitesh D. Raviya, Professor and Head, Department of English, Faculty of Arts, The Maharaja Sayajirao University of Baroda, Vadodara E-mail: hitesh.raviya-eng@msubaroda.ac.in}

